\title{
Lacrimal Gland Carcinoma pT1c TNM Finding v8
}

National Cancer Institute

\section{Source}

National Cancer Institute. Lacrimal Gland Carcinoma pT1c TNM Finding v8. NCI

Thesaurus. Code C140787.

Lacrimal gland carcinoma with tumor measuring $2 \mathrm{~cm}$ or less in greatest dimension with or without extraglandular extension into the orbital soft tissue with periosteal and bone involvement. (from AJCC 8th Ed.) 